AGREGAT:JurnalEkonomidanBisnis

Vol. 3, No. 1, Maret 2019

http://journal.uhamka.ac.id/index.php/agregat

p-ISSN: 2549-5658 e-ISSN: 2549-7243

DOI: 10.22236/agregat_vol3/is1pp25-34

Hal 25-34

\title{
ANALYSIS THE QUALITY OF SERVICE AND EFFECTIVENESS E-COMMERCE AUY PUBLISHER USING THE METHOD E-SERVQUAL
}

\author{
Atik Budi Paryanti , Sumarsid \\ Sekolah Tinggi Manajemen LABORA \\ Email: atikbudiparyanti@gmail.com
}

Diterima: 4 Januari 2019; Direvisi: 7 Januari 2019; Disetujui: 10 Januari 2019

\begin{abstract}
This research aims to analyze the quality of the service and the effectiveness of Ecommerce. This research uses a quantitative approach. Data analysis using the pras test test validity and reliability as well as a test of normality. At this stage of the analysis of data with calculations e-servqual will get the service quality level e-Commerce and the calculation of $e$-Commerce It can also analyze the priority of each service attribute that needs to be fixed or not. The questionnaire will be filled is given to respondents with Nonprobability Sampling technique. This study use 46 participant. The Total value of Electronic Service Quality (TESQ) obtained from the results of the calculation of the gap between perception and expectation is positive, the results obtained are 0226 . This means that the customer's expectations of the service $e$-Commerce in larger AUY Publisher from the Ministry obtained this time, so that the service provided is still not satisfying customers and has not been effective $\left(X_{2}\right)$.
\end{abstract}

Keywords: Service quality, effectiveness, e-commerce, e-servqual, electric service quality

\begin{abstract}
Abstrak
Penelitian ini bertujuan untuk menganalisis kualitas layanan dan efektivitas Ecommerce. Penelitian ini menggunakan pendekatan kuantitatif. Uji prasyarat analisis data menggunakan uji validitas dan reliabilitas serta uji normalitas. Pada tahap analisis data dengan perhitungan e-Servqual akan didapat tingkat kualitas layanan e-Commerce dan dari perhitungan -Commerce juga dapat menganalisis prioritas dari tiap atribut layanan yang perlu diperbaiki ataupun tidak. Kuesioner yang akan diisi diberikan kepada responden dengan teknik Nonprobability Sampling. Sampel dalam penelitian ini sebanyak 46 orang. Dari nilai Total Electronic Service Quality (TESQ) yang diperoleh dari hasil perhitungan kesenjangan antara persepsi dan harapan bernilai positif, hasil yang diperoleh adalah 0.226. Artinya harapan pelanggan terhadap layanan e-Commerce di Penerbit AUY lebih besar dari pelayanan yang diperoleh saat ini, sehingga pelayanan yang diberikan masih belum memuaskan pelanggan dan belum efektif.
\end{abstract}

Kata Kunci:kualitas servis, efektivitas, e-commerce, e-servqual, kualitas servis elektrik 


\section{INTRODUCTION}

The value of trading via internet in Indonesia among year 2009 was more than $\$ 3.4$ billion or approximately $\$ 44$ trillion. The number of internet users reached 17 million and the value of e-Commerce who also reached 3.4 billion u.s. dollars of this rated as a potential online market and that number continues to grow in the next years (Darmawan and Chandrataruna, 2009).

The potential market is perceived by the leadership of Publisher AUY. Publishers book publishing company AUY that focus to books in the field of health. The Publisher has a distinctive market AUY, i.e. student health sciences clumps. Health Sciences student belongs to a group of students who did not have a lot of spare time. A dense lecture activities, tasks, as well as the practice of confiscating most of their time. Need for books is high especially with the enactment of the method of learning Problem Based Learning (PBL) that requires self-study. This condition becomes a market opportunity for Publishers AUY to present their products on the market e-Commerce in order to be easy to reach the target market because of the kodisi, the Publisher of the AUY make a e-Commerce, which is currently e-Commerce has been running for about 1 year.

Publishers should be able to make the AUY customers to buy its products. Ability to understand customer satisfaction and how to make a buying decision is absolutely required. The main factors of customer satisfaction is the perception of the quality of customers service/service (Zeithamal and Bitner, 2006). Previous research tells us that the quality of service is an important indicator of customer satisfaction (Spreng and Machoy, 1996).

Model quality services are the most popular and up to now many made reference in research management and marketing services is a model Service Quality (Servqual) developed by Parasuraman, Zeithaml and Berry, (1985-1994) (Tjiptono and Chandra, 2016:149). Method Servqual This later developed into e-Servqualessentially, this model is an adaptation and expansion of the model Servqual into the context of the online shopping experience. The measurement of service quality in the model e-Servqual This is based on a multiple-item scale designed to measure the expectations and perceptions of customers, as well as the gap between the two main dimensions of 7 (efficiency, reliability, fulfillment, privacy, responsiveness, compensation, and contacts) (Tjiptono and Chandra, 2016:178). the Seven main dimensions are translated into the respective detailed attributes for the variable variable expectations and perceptions, compiled statements based on Likert scale, from 1 (strongly disagree) to 5 (strongly agree). Quality evaluation of services using a model Servqual includes calculation of the difference between the value given the customers for each pair of statements relating to expectations and perception (Tjiptono and Chandra, 2016:159).

In General, analysis is the investigation against an event (bouquet, deeds, etc.) to know the actual state of Affairs (causes, sat subjects, and so on); or a tree decomposition of various his share and review the section 
AGREGAT:JurnalEkonomidanBisnis

Vol. 3, No. 1, Maret 2019

http://journal.uhamka.ac.id/index.php/agregat

p-ISSN: 2549-5658 e-ISSN: 2549-7243

DOI: 10.22236/agregat_vol3/is1pp25-34

Hal 27

itself and the relationship from to obtain the proper understanding and the understanding of the meaning of the whole. He describes it as a thinking activity analysis to elaborate a whole into component so that it can recognize the signs of the components, their relationship to each other and their respective functions in one integrated whole ( $\mathrm{He}$ and Yooke, 2000).

Goetsch and Davis (2010) in Tjiptono (2016) defines quality as the dynamic conditions relating to a product, service, human resources, processesandenvironments that meet or exceed expectations. Quality is a function of costs where costs can be lowered with the repair process or the reduction of variation in the product or variations in the process (Tjiptono and Chandra, 2016:115).

Quality of service is the company's understanding about customers to create superior value for customers on an ongoing basis (Taylor, 2001). Every company vying improve service to its customers in order to seize the market. Quality of service is one of the keys to success for the company in the face of the increasingly keen competition era (sustainable and Mufattahah, 2009).

Kim and Moon in 1998 stated that $e$ Commerce is the process of deliver information, products, services and payment processing, phone cable, internet connection and access other digital.Baourakis, Kourgiantakis, and Migdalas in the year 2002 States that $e$-Commerce is a form of per-trade goods and information through the internet network.Quayle in the year 2002

also didn't want to lose to add-kan definition of e-Commerce. e-Commerce defined as the various forms of electronic data interchange or Electronic Data Interchange (EDI) which involves the buyer and seller through E-Mail, mobile device, mobile, connected devices in an internet network.

Chaffey in 2007 refine again definition of e-Commerce, by considering that the year 2007 developmentcomputer technology and the internet has added a change in e-Commerce, with the emergence of diverse security technologies, online payment technologies, mobile devices (Smartphone,Mobile, Tablet), the increasing number of organisations and peng-to theconnect to the internet, and muncunya a variety of web-based application development technologies. So then congressional repair of difinisi e-commerce. e-commerce is defined as all forms of processthe exchange of information between organizations and stakeholder-based electronic media network that connects to the internet (I Putu Agus Eka Pratama, 2015:2).

Model quality services are the most popular and up to now many made reference in research management and marketing services is a model Service Quality (Servqual) developed by Parasuraman,Zeithaml, and Berry (1985-1994). Through a survey done by Parasuraman, Zeithaml andBerry set a dimension to measure the quality of a service, where the dimensions are then known by the name of Servqual in ten dimensions (James Jiang, Gary Klein: 2002). 


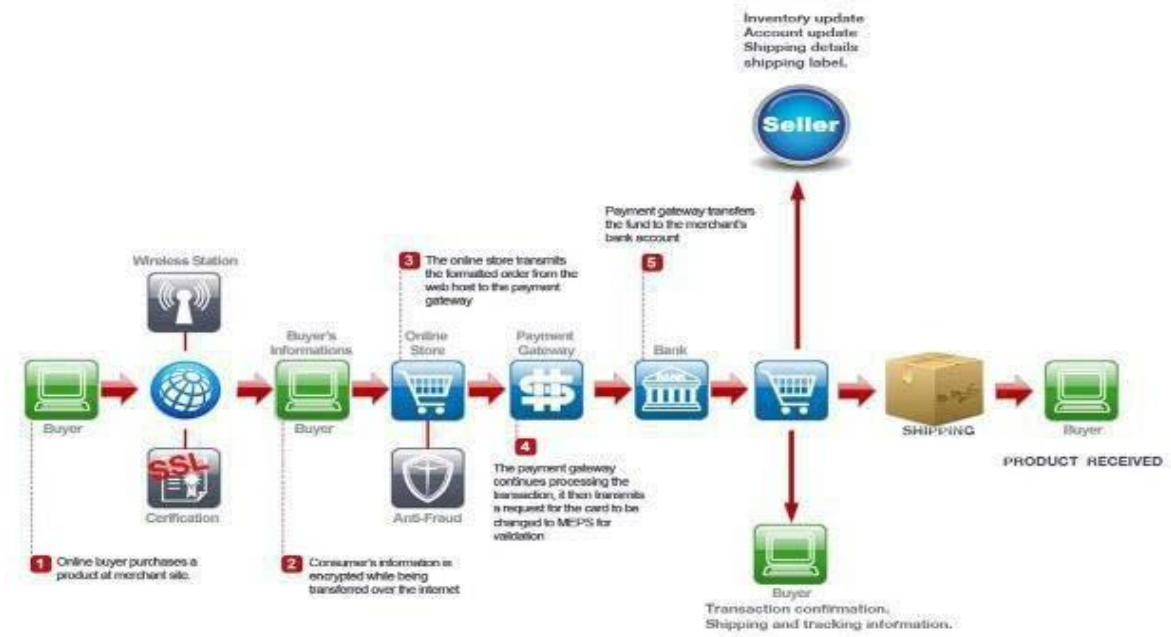

Figure 1. Groove activities on E-Commerce (Source: I Putu Agus Eka Pratama, 2015:8)

In its development then the tenth, the component in compress into five dimensions which became a reference for measurements in do Customer against IE (James Jiang, Gary Klein: 2002) Reliability, The ability to have better performance in its mainstay can andaccurate.Assurance, The ability of the members to give rise to a sense of believe and securely to customers. Tangibles, The visible aspect of the mass physical equipment and personnelthe officer. Empathyincludes kepedullian as well as individual attention to ourusers.Responsiveness, i.e. the willingness to assist participants andgiving proper attention.

Model servqual there are 5the main gap, i.e., the knowledge gap, gap, gap's delivery standards, communication gaps, service gap. These models illustrate in Figure 2.2 in. The horizontal dotted lines separate the two major phenomena: the upper part is a phenomenon related to the customers and the bottom refers to a phenomenon in the company or the service provider (Tjiptono and Chandra, 2016:149-152).

Method Servqual. This later developed into e-Servqual essentially, this model is an adaptation and expansion of the model Servqual into the context of the online shopping experience. In the e-servqual model there are 4 kinds of gap, i.e. the information gap, gap, communication design, and fulfillment gab gap (see Figure 2.3). A conceptual framework for integrating two major aspects: (1) an assessment of the quality of customer service is electronic and the consequences and (2) the weakness of the organization can contribute to the assessment of the quality of service is crappy electronics.

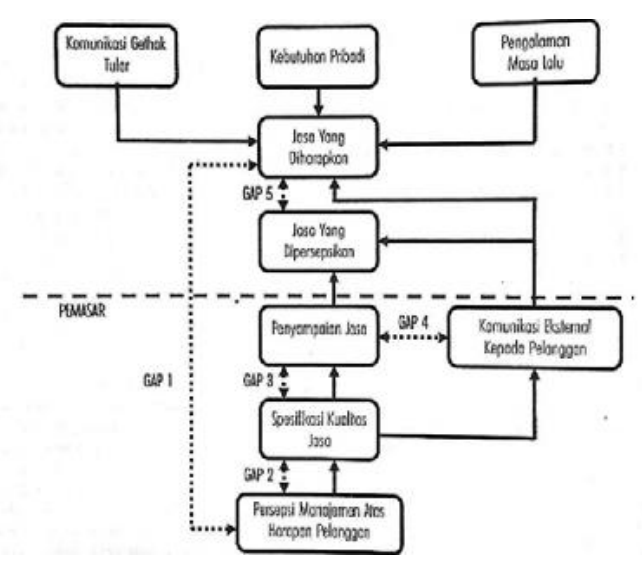

Figure 2. conceptual Model Servqual (Source: Zeithaml, et al., 1990) 


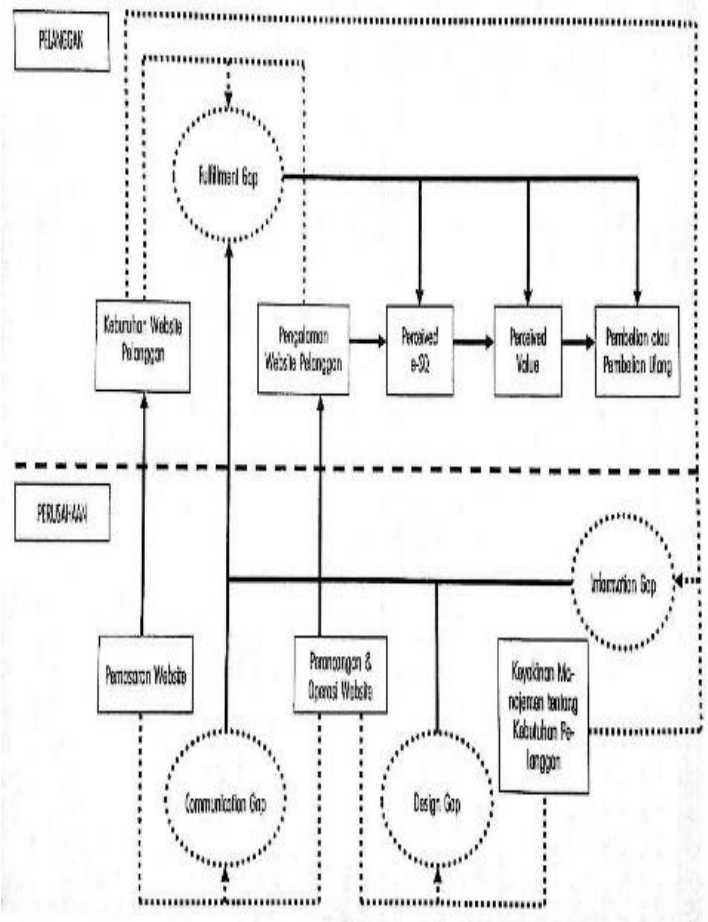

Figure 3. Conceptual Models e-servqual (Source: Zeithaml, et al., 1990)

\section{METODOLOGI RESEARCH}

This research uses a quantitative approach.

Test the validity of using IBM SPSS

Statistics programme 22 . Reliability test will be done by the method of Cronbach's

Alpha counting is done by calculating the average interkorelasi of which the details of the statement in kuisoner (Kurniawan, 2008).

The calculation of the e-Servqual on the research in accordance with the steps and formulas described by Tjiptono and Chandra (2016). The result of the calculation e-Servqual It can determine the level of quality of service $e$-Commerce given unsatisfactory or not (Tjiptono and Chandra, 2016:159).

The analysis data in this study was conducted to analyze the results of data obtained from the processing of the data. From the results of a calculation e-Servqual will get the service quality level e-Commerce and the calculation of $e$-Commerce It can also analyze the priority of each service attribute that needs to be fixed or not. Questionnaire likert scale is done using the with range 1 to 5 to answer strongly disagree to strongly agree answers.

The questionnaire will be filled is given to respondents with Nonprobability Sampling technique, namely the sampling techniques that do not give the same opportunity to opportunity/every element or members of the population to be selected into the sample (Sugiyono, 2007:66). Researchers then use method convenience samples, i.e. sampling conducted in accordance with the provisions or requirements of a sample of certain populations of the most easily accessible or was obtained by investigators. This study uses 46 participants.

\section{RESULTS AND DISCUSSION}

The value of the e-Servqual per variable or declaration sought by calculating the average value (meandata from the results) the perception and expectations of each statement. Once known to the average value of each statement's perception and expectation, then the average value of the perception of the average value of reduced expectations that would later produce the value gap (gap) of each variable or declaration. As shown in Table 1.

\begin{tabular}{|c|c|c|c|}
\hline \multicolumn{4}{|c|}{ The results of the e-Value Sevqual per Variable/ } \\
Statement \\
\hline No & $\begin{array}{c}\text { Perception } \\
\text { (P) }\end{array}$ & Hope (E) & The Gap (Q) \\
\hline 1 & 3.283 & 3.674 & -0.391 \\
\hline 2 & 3.522 & 3.870 & -0.348 \\
\hline 3 & 3.587 & 3.913 & -0.326 \\
\hline 4 & 3.761 & 3.891 & -0.130 \\
\hline
\end{tabular}




\begin{tabular}{|c|c|c|c|}
\hline 5 & 3.565 & 3.935 & -0.370 \\
\hline 6 & 3.957 & 3.848 & 0.109 \\
\hline 7 & 3.543 & 3.957 & -0.413 \\
\hline 8 & 3.522 & 3.957 & -0.435 \\
\hline 9 & 3.674 & 3.935 & -0.261 \\
\hline 10 & 3.935 & 3.891 & 0.043 \\
\hline 13 & 3.804 & 3.891 & -0.087 \\
\hline 14 & 3.717 & 3.891 & -0.174 \\
\hline 15 & 3.978 & 3.761 & 0.217 \\
\hline 16 & 3.674 & 3.826 & -0.152 \\
\hline 17 & 3.826 & 3.848 & -0.022 \\
\hline 19 & 3.478 & 4.000 & -0.522 \\
\hline 20 & 3.674 & 3.783 & -0.109 \\
\hline 21 & 3.761 & 3.804 & -0.043 \\
\hline 22 & 3.674 & 3.826 & -0.152 \\
\hline 23 & 3.543 & 3.913 & -0.370 \\
\hline 24 & 3.413 & 3.891 & -0.478 \\
\hline 25 & 3.870 & 4.043 & -0.174 \\
\hline 26 & 3.435 & 3.935 & -0.500 \\
\hline 27 & 3.587 & 3.913 & -0.326 \\
\hline$T$
\end{tabular}

Table 1. Result Value e-sevqual per Variable

The results of calculations on TAbel 1 . Seen that statement No. 16 has the largest negative gaps i.e.-0522, statement No. 16 giving customers the average value of the lowest perception that where customers are less satisfied against the sector. Otherwise on no. 13 has the largest positive gaps i.e. 0217, statement No. 16 giving customers the average value of the lowest perception that where customers are less satisfied against the sector. Otherwise on no. 13 has the largest positive gaps i.e. 0217 , where in the customer gives an average value of considerable perception which was quite satisfied with customer service in the sector.

The value e-Servqual per variable/ statement is known, then do the calculations to find the value of e-Servqual for each dimension. Researchers divided into 9 dimensions where each service represents a dimension e-Commerce It takes customers. The dimensions are determined based on the grouping of statements contained in the questionnaire. Calculations for e-Servqual per the dimensions not too far from the calculation $e$-Servqual per variable.

The difference is visible only on the results of value e-Servqual per variable is obtained, then performed in which the average value and sought after. For the complete results can see table 2 .

\begin{tabular}{|c|l|c|c|c|}
\hline No & \multicolumn{1}{|c|}{ Dimensions } & $\mathrm{P}$ & $\mathrm{E}$ & $\mathrm{Q}$ \\
\hline 1 & Growing (Real) & 3.538 & 3.837 & -0.299 \\
\hline 2 & Reliability & 3.647 & 3.924 & -0.277 \\
\hline 3 & Responsiveness & 3.804 & 3.913 & -0.109 \\
\hline 4 & Assurance & 3.833 & 3.848 & -0.014 \\
\hline 5 & Emphaty & 3.750 & 3.837 & -0.087 \\
\hline 6 & $\begin{array}{l}\text { Lack of Annoying } \\
\text { Banners }\end{array}$ & 3.478 & 4.000 & -0.522 \\
\hline 7 & $\begin{array}{l}\text { Online Assistance } \\
\text { (Help Online) }\end{array}$ & 3.717 & 3.793 & -0.076 \\
\hline 8 & Ease of Use & 3.543 & 3.877 & -0.333 \\
\hline 9 & $\begin{array}{l}\text { Site Security and } \\
\text { Respon Time }\end{array}$ & 3.630 & 3.964 & -0.333 \\
\hline
\end{tabular}

Table 2 results of e-Value

Sevqual per Dimension

From the results shown in table 2, it can be concluded that in dimensions Lack of Annoying Banners (There are no annoying banner) has an average of the largest negative gaps i.e.-0522. Where the customers are not satisfied will service or feature provided by e-Commerce Publisher AUY. Different dimensions Assurance (Assurance), on this dimension has the lowest negative gap IE0.014. Where the customer feels dissatisfied will also service provided, but not as big as in the other dimension.

The value of TSEQ (Total Electronic Service Quality) required for testing the hypothesis that was already written by the researchers. The value of TESQ knowable by performing calculations by finding gaps (gap) of the average total perception and expectations throughout the respondents, as 
AGREGAT:JurnalEkonomidanBisnis

Vol. 3, No. 1, Maret 2019

http://journal.uhamka.ac.id/index.php/agregat

p-ISSN: 2549-5658 e-ISSN: 2549-7243

DOI: 10.22236/agregat_vol3/is1pp25-34

Hal 31

described below in table 3 .

\begin{tabular}{|c|c|c|c|}
\hline No & It & PS & Q \\
\hline 1 & 3.458 & 4.417 & -0.958 \\
\hline 2 & 1.750 & 2.458 & -0.708 \\
\hline 3 & 1.000 & 3.833 & -2.833 \\
\hline 4 & 4.042 & 4.458 & -0.417 \\
\hline 5 & 4.000 & 4.458 & -0.458 \\
\hline 6 & 4.042 & 3.458 & 0.583 \\
\hline 7 & 3.792 & 3.792 & 0.000 \\
\hline 8 & 4.250 & 3.958 & 0.292 \\
\hline 9 & 3.917 & 3.750 & 0.167 \\
\hline 10 & 4.000 & 3.875 & 0.125 \\
\hline 11 & 3.333 & 3.042 & 0.292 \\
\hline 12 & 4.000 & 3.125 & 0.875 \\
\hline 13 & 3.417 & 3.167 & 0.250 \\
\hline 14 & 3.750 & 3.125 & 0.625 \\
\hline 15 & 3.083 & 4.042 & -0.958 \\
\hline 16 & 4.000 & 5.000 & -1.000 \\
\hline 17 & 5.000 & 4.875 & 0.125 \\
\hline 18 & 4.208 & 3.917 & 0.292 \\
\hline 19 & 3.083 & 3.667 & -0.583 \\
\hline 20 & 4.750 & 4.125 & 0.625 \\
\hline 21 & 4.833 & 4.083 & 0.750 \\
\hline 22 & 4.833 & 1.750 & 3.083 \\
\hline 23 & 4.875 & 4.000 & 0.875 \\
\hline 24 & 3.625 & 2.833 & 0.792 \\
\hline 25 & 3.000 & 4.000 & -1.000 \\
\hline 26 & 3.875 & 4.500 & -0.625 \\
\hline 27 & 3.333 & 4.417 & -1.083 \\
\hline 28 & 3.792 & 2.875 & 0.917 \\
\hline 29 & 4.083 & 3.375 & 0.708 \\
\hline 30 & 3.500 & 2.042 & 1.458 \\
\hline 31 & 4.708 & 3.083 & 1.625 \\
\hline 32 & 4.542 & 3.958 & 0.583 \\
\hline 33 & 4.417 & 4.458 & -0.042 \\
\hline 34 & 4.250 & 2.958 & 1.292 \\
\hline 35 & 4.458 & 3.083 & 1.375 \\
\hline 36 & 4.208 & 3.625 & 0.583 \\
\hline 37 & 4.542 & 4.292 & 0.250 \\
\hline 38 & 4.375 & 3.792 & 0.583 \\
\hline 39 & 4.625 & 3.708 & 0.917 \\
\hline 40 & 4.375 & 5.000 & -0.625 \\
\hline 41 & 4.125 & 3.917 & 0.208 \\
\hline 42 & 3.750 & 2.875 & 0.875 \\
\hline 43 & 3.667 & 3.000 & 0.667 \\
\hline 44 & 3.083 & 3.500 & -0.417 \\
\hline 45 & 3.458 & 3.625 & -0.167 \\
\hline 46 & 3.417 & 2.958 & 0.458 \\
\hline Average & 3.883 & 3.658 & 0.226 \\
\hline
\end{tabular}

Table 3. The Result Value of TESQ

Based on the value of TESQ, with total value of 3,883 ice is and PS is 3,658, sehinggan value e-Servqual obtained as a whole is 0226 . With the value obtained proved that the services provided e-Commerce Publisher AUY currently satisfy customers and ineffective. As the results obtained from the respondents, where expectations are greater than the perception. As explained on the sub chapter (3.2.3.2) when the value of the ICE > PS then "Less satisfied" Customers, when the value of the ICE = PS then "customer satisfied", and if the value of the ICE then "PS $<$ Customers very satisfied".

The result of the processing of data as the proposed improvements in the e-Commerce AUY Publisher future. to determine priority repair service e-Commerce the Cartesian diagram, used aslook at Figure 4.

Quadrant A shows the statement/ variablerated very important by customers who use e-Commerce but in fact it is still not satisfactory(customer perception is low, while high customer expectations). Quadrant A requires handling that need to be prioritized in the improved quality due to pass the attributes in this quadrant are considered very important by customers who use e-Commerce but his Ministry is not satisfactory so that the parties should enhance the quality of the AUY Publisher of his Ministry.

P2: E-Commerce Publisher AUY typical design how it looks

P3: E-Commerce Publisher AUY has a neat design and regularly

P5: E-Commerce Publisher AUY provide ease the process of transacting 


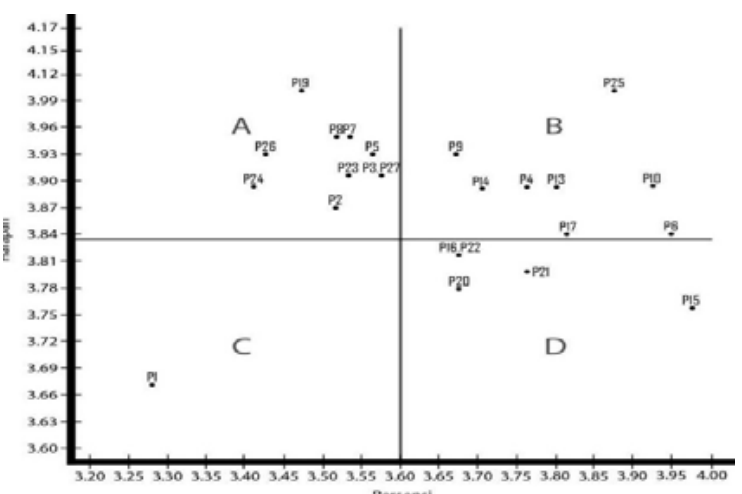

Figure 4 Repair Service e-commerce publisher AUY

P7: E-Commerce Publisher AUY guarantee timeliness

P8: E-Commerce Publisher AUY suppress occurrence of error record

P19: information required to appear without any interruption

P23: E-Commerce Publisher AUY gives ease in transaction products

P24: Website is very flexible to interact P26: Quick website Responses

P27: Customer don't have to wait long in transacting through E-Commerce Publisher AUY

Statement on the quadrant B isthe statement/variable that needs to be fixed and needs to be maintained because of customers who use e-Commerce has been satisfied with the service but customerswant services provided better again. But even though so there is still a negative values in this quadrant. In the table below can be seen attributes contained on the B quadrant along with order of priority improvements to its services.

P4 : Appearance of E-Commerce Publisher AUY correspond to the products offered. P6 : E-Commerce Publisher AUY credible/ reliable.

P9 : E-Commerce Publisher AUY shows his role in resolving problems quickly

P10 : Customer Service E-Commerce Publisher AUY always expanding the number to help customers

P13 : Customer Service E-Commerce Publisher AUY have politeness and hospitality towards its customers

P14 : Customer Service E-Commerce Publisher AUY has knowledge of the products offered

P17 : customer service via social media are the current trends

P25 : Guaranteed secure customer information

Statement on the quadrant $\mathrm{C}$ isthe area of low priority because the statement/ variable in this quadrant are considered less important or not by the user and his Ministry was less satisfactory. But that does not mean the statement/variable in the quadrants of this not being a thing that should be noted because future statements or those attributes could be the demands on behalf of the AUY in running quality of service. In the following table can be seen the statement/variable contained in quadrant $\mathrm{C}$, along with order of priority repair.

P1 E-Commerce Publisher AUY has an interesting look with the fonts, colors, graphics, and pictures that support each other statement on the quadrant $\mathrm{D}$ isthe statement is considered important but less satisfying customers. In the following table can be seen the statement/variable found in the quadrant D along with the order of priority of its repair. E-commerce. Publisher p15 AUY has availability of information office address and contact number 
AGREGAT:JurnalEkonomidanBisnis

Vol. 3, No. 1, Maret 2019

http://journal.uhamka.ac.id/index.php/agregat

p-ISSN: 2549-5658 e-ISSN: 2549-7243

DOI: 10.22236/agregat_vol3/is1pp25-34

Hal 33

P16 : Ease customers contact and speak with

a Customer Service E-Commerce Publisher

AUY

P20 : Terdapatnya live chat feature

P21 : Terdapat column article that contains important information and knowledge about the product

P22 : E-commerce Publisher AUY clear and easy to understand

\section{CONCLUSION}

Based on the value of the e-Servqual per variable (statement), gap or the gap is highest for service $e$-Commerce It is on the 16th of variable-0522 (ease of customer contact and talk with E-Commerce Customer Service Publisher AUY). The value of the $e$ Servqual the lowest variable exists in the variables of 0217 (E-Commerce Customer Service Publisher AUY have politeness and hospitality towards its customers).

The value of e-servqual per dimension shows all values $e$-Servqual each of the dimensions is negative, meaning that all services $e$-Commerce towards customers has not been satisfactory. Dimension with a value of e-Servqual the highest is the dimension of Lack of Annoying Banners i.e.registration-0522, whereas the value of e-servqual dimensions is the lowest Assurance registration-0.014.

The Total value of Electronic Service Quality (TESQ) obtained from the results of the calculation of the gap between perception and expectation is positive, the results obtained are 0226. This means that the customer's expectations of the service $e$ Commerce in larger AUY Publisher from the Ministry obtained this time, so that

the service provided is still not satisfying customers and has not been effective. The service improvement priorities take precedence is a service that resides on a quadrant.

\section{REFERENCE}

Daryanto. (2010). Learning, Media: His Role Is Very Important In Achieving Learning Objectives. Yogyakarta : Gaya Media

Fandy, Tjiptono G and Chandra. (2016). Service, Quality and Satisfaction's Edition 4. Yogyakarta : Publisher of Andi.

I Putu Agus Eka Pratam. (2015). ECommerce, E-Business, and Mobile Commerce: Open Source-Based. Bandung : Publisher of Informatics.

December, John. (1997). The WorldWide Web 1997 unleashed. US : Indianapolis.

He and Tjuparnah S. (2000). Yooke, Dictionary Of Scientific Paper.Jakarta : Earth Revised.

Kuncoro, E. A. and Riduwan. (2007). How to use and interpret the path analysis. Bandung : Alfabeta Publisher

MacBride. (1995). Self Study Internet, Printing HOUSE. Bekasi : Translation Sugeng Panut.

Nasution. (2010). Integrated quality management: Total Quality Manajement. Jakarta : Ghalia.

Strauss, Judy, Adel, E, and Raymond F. (2003). E-Marketing. Third Edition, New Jersey: Prentice Hall.

Sugiyono. (2007). Statistics for research. Bandung : Alfabeta, Publisher.

Yamit, Zulian. (2002). Quality management products and services. Yogyakarta : Ekonisia, 2002.

Zeithaml, V. A. Parasuraman, A and 1. 1. Berry. (1990). Delivering Quality Service. New York : The Free Press.

Astuti, d., \& Salisah, f. n. (2016). Analysis Of The Quality Of E-Commerce Services Towards Customer Satisfaction Using 
E-Servqual, 2(1), 44 - 49.

Berisha-shaqiri, A. (2015). Management Information System and Competitive Advantage. 6(1). 204-208. https://doi. org/10.5901/mjss.2015.v6n1p204

Bharati, P., \& Tarasewich, P. (2002). Global perceptions of journals publishing ecommerceresearch.Communications of the ACM, 45(5). https://doi. org/10.1145/506218.506235

Carey, P. (2001). The Internet And ECommerce.https://doi.org/10.1016/ S0140-6736(10)60272-3.

Chandra, A. S. (2014). The influence of e-Servqual Towards Customer Satisfaction,Trust, and Repeat Usage of Mobile Bca Services.

Darmawan, \& Chandrataruna. (2009). The development of E-Commerce in Indonesia.

Goddess, r. n., \& Wardati, i. u. (2013). The Design Of The System Of Madrasah Ibtidaiyah Profile Website Creation The Country Brought In Pacitan. English Journal on Networking and Security.

Ghandour, A., Benwell, G., \& Deans, K. (2010). Measuring the performance of ecommerce websites. Proceedings of PACIS. 284-295.

Harsono, D., Unardi, J. O. K. O. S., Iantara, D. E. S. I. B., High, S., Nuclear, T. (2009). Temperature monitoring with microcontroller atmega 8 on the local network,. $415-422$.

Jiang, J. J., Klein, G., Carr, C. L., Klein, G., \& Carr, C. L. (2002). Measuring Information System Service Quality: Servqual From The Other Side. 26(2), 145-166.

Kurniawan, M. B. (2008). The efforts of improving the services Users Flexi inSurakarta Using Servqual Gap In Pt. Telkom Surakarta.
Lestari, S. E. and Mufattahah, s. (2009). Customer satisfaction and service quality at the Centre of development and empowerment of educators and educational power jakarta, languages 2(2), $176-182$.

Nemati, B., Gazor, H., Mirashrafi, S. N., \& Ameleh, K. N. (2012). Analyzing e-service quality in servicebased website by E-SERVQUAL. Management Science Letters, 2, 727$734 . \quad$ https://doi.org/10.5267/j. $\underline{\mathrm{msl}} .2011 .12 .002$

Nogoev, A., Yazdanifard, R., Shahriar, M., \& Behrang, S. (2011). The Evolution and Development of E-Commerce Market and E-Cash, 0, 5-10.

Pratama, I. P. A. E. (2015). E-Commerce, EBusiness, and Mobile Commerce:Open Source-Based. Publisher Information (Vol. 1).

Rababah, O. M. A., \& Masoud, F. A. (2010). Key Factors for Developing a Successful E- commerce Website, https://doi.org/10.5171/2010.763461

Spreng, R. A., \& Mackoy, R. D. (1996). An Empirical Examination of a Model of Perceived Service Quality and Satisfaction. Journal of Retailing. 72(2), 201- 214. https://doi. org/10.1016/S0022-4359(96)90014-7

Zeithaml, V. a., Parasuraman, a., \& Malhotra, a. (2002). Service Quality Delivery through Web Sites: A Critical Review of Extant Knowledge. Journal of the Academy of Marketing Science, 30(4), 362375.https://doi. org/10.1177/00920700223691 